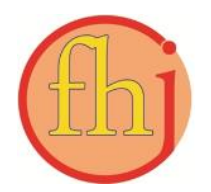

Faletehan Health Journal, 8 (3) (2021) 203-209

www. journal.Ippm-stikesfa.ac.id/ojs/index.php/FHJ

ISSN 2088-673X | e-ISSN 2597-8667

\title{
Dampak Persepsi dan Stigma Masyarakat tentang Covid-19
}

\author{
Ernawati Umar ${ }^{1 *}$, Dedeh Hamdiah ${ }^{1}$ \\ ${ }^{1}$ Program Studi Keperawatan, Universitas Sultan Ageng Tirtayasa \\ *Correspondence Author: ernawatiumar08@gmail.com
}

\begin{abstract}
Abstrak
Wabah Covid-19 di Indonesia, tertanggal 15 November 2020 telah menjangkiti 474.455 orang dan dinyatakan positif covid, data pasien sembuh berjumlah 398.636 orang, sementara yang meninggal mencapai 15.393 orang. Persepsi negatif dan stigma menyerang orang-orang yang berhubungan dengan Covid-19 serta dapat menimbulkan stres dan depresi sehingga dapat menurunkan imunitas tubuh yang menyebabkan kematian. Penelitian ini bertujuan untuk mengetahui persepsi dan stigma masyarakat tentang Covid 19 di Provinsi Banten pada tahun 2020. Penelitian ini bersifat descriptive analitik dengan menggunakan pendekatan studi potong lintang untuk melihat persepsi dan stigma masyarakat yang terpapar dengan covid 19. Penelitian dilakukan pada bulan Juni - Nopember 2020 di Kabupaten Pandeglang dan Kota Serang. Pengambilan data melalui penyebaran kuesioner. Sampel penelitian sebanyak 750 Responden. Hasil Penelitian menunjukkan adanya hubungan yang signifikan antara persepsi masyarakat dan stigma negatif masyarakat yang mempengaruhi kinerja tenaga kesehatan dan tingkat stress pasien covid dan dengan nilai $P$ ( $p$ value) keduanya $=0,00$. Persepsi dan stigma negatif akan berdampak terhadap kinerja tenaga kesehatan dan menimbulkan depresi pada pasien covid-19 yang mengakibatkan menurunnya sistem imun.
\end{abstract}

Kata Kunci: Covid 19, Persepsi Masyarakat, Stigma Masyarakat

\section{Community Perception and Stigma about Covid-19}

\begin{abstract}
Covid-19 outbreak in Indonesia, dated November 15, 2020, infected 474.455 people who were tested positive, 398.636 people were recovered, while 15.393 people died. Negative perception and stigma attacked people related to Covid-19 and caused stress and depression which can reduce the immune system then cause death. This study aimed to determine the community perception and stigma about Covid 19 in Banten Province in 2020. This study was analytical descriptive and used a cross-sectional study approach to examine the perception and stigma of community who were infected by covid 19. This study was conducted from June to November 2020 in Pandeglang Regency and Serang City. The data collection was by distributing questionnaires. The samples were 750 respondents. This study found a significant relationship between community perception and community stigma, which influences the performance of health workers and the stress level of Covid-19 patients with $p$ value 0.00 for both. Negative perception and stigma may impact on the performance of health workers and cause depression in COVID-19 patients, which results on the decrease of immune system.
\end{abstract}

Keywords: Covid-19, Community Perception, Community Stigma 


\section{Pendahuluan}

Penyakit Covid 19 saat ini telah menjadi pendemi di dunia karena sudah 220 Negara mengalami wabah tersebut dan telah menjangkiti penduduk dunia dengan angka kematian 1.317.320. Di Indonesia, Wabah Penyakit Covid-19, tertanggal 15 Nopember 2020 telah menjangkiti 474.455 orang, pasien yang sembuh berjumlah 398.636 orang, sedangkan yang meninggal mencapai 15.211 orang. Angka ini terus bertambah setiap harinya. Hingga saat ini, belum ada pengobatan yang dapat menyembuhkan infeksi virus Corona, demikian juga belum selesai uji coba penggunaan vaksin covid-19 untuk manusia. Oleh sebab itu, Organisasi Kesehatan Dunia (WHO) mengimbau agar masyarakat tidak memandang sepele penyakit ini dan senantiasa melakukan tindakan pencegahan. Salah satunya adalah dengan menerapkan social distancing, cuci tangan, memakai masker, dan diam di rumah saja jika tidak ada kepentingan yang mendesak (Compass, 2019). Sugesti yang sempat mampir sejenak bahwa Indonesia kebal corona memperkuat kecemasan ketika masyarakat menatap nanar lonjakan angka pasien yang terdeteksi positif penyakit Covid-19 disertai dengan fatality rate akibat penyakit Covid19 yang mencapai 4,3 persen atau tiga besar setelah Italia dan Iran. Keyakinan bahwa orang Indonesia sakti dan kebal corona ternyata delusi (Kumar, 2020; Mona, 2020).

Berdasarkan data kasus pasien penyakit Covid-19 dari Kementerian Kesehatan kasus positif penyakit Covid-19 di Provinsi Banten terdapat 180 kasus baru, sehingga akumulasi kasus sebanyak 15.969, pasien sembuh bertambah 5 orang hasil akumulasinya 9.811 kasus, dengan kondisi ini Provinsi Banten masuk dalam 10 besar Provinsi dengan jumlah kasus terbesar (Zonabanten.com).

Pandemik penyakit covid-19 hingga saat ini masih mengalami peningkatan sehingga masyarakat saat ini terhantui oleh isolasi diri. Masyarakat mempunyai persepsi yang berbeda beda terhadap orang yang ODP (Orang Dalam Pemantauan), PDP (Pasien Dalam Pengawasan) dan Orang dengan Positif Covid 19, karena banyaknya informasi tentang penyakit Covid 19 baik di Televisi, media informasi maupun Media Sosial sehingga semakin membuat masyarakat bingung dan resah. Demikian juga di tengah wabah penyakit Covid-19, muncul satu fenomena sosial yang berpotensi memperparah situasi, yakni stigma sosial atau asosiasi negatif terhadap seseorang atau sekelompok orang yang mengalami gejala atau menyandang penyakit tertentu, juga pada kelompok orang yang berhubungan dengan pasien tersebut seperti perawat, dokter, tenaga Kesehatan lain, dan keluarganya Mereka diberikan label, stereotip, didiskriminasi, diperlakukan berbeda, dan/atau mengalami pelecehan status karena terasosiasi dengan sebuah penyakit.

Covid 19 merupakan jenis penyakit baru dan belum banyak diketahui tentang pandemi Covid19 , terlebih manusia cenderung takut pada sesuatu yang belum diketahui dan lebih mudah menghubungkan rasa takut pada "kelompok yang berbeda/lain" (Nilam, 2020). Inilah yang menyebabkan munculnya stigma sosial dan diskriminasi terhadap etnis tertentu dan juga orang yang dianggap mempunyai hubungan dengan virus ini. Perasaan bingung, cemas, dan takut yang dirasakan dapat dipahami, tapi bukan berarti boleh berprasangka buruk pada penderita, perawat, dokter, keluarga, ataupun mereka yang tidak sakit tapi memiliki gejala yang mirip dengan penyakit Covid -19, menurut, Arifiati et al., (2020); Kim et al., (2020). Jika terus terpelihara stigma negatif di masyarakat, dapat membuat orang-orang yang terpapar penyakit Covid-19, menyembunyikan sakitnya supaya tidak didiskriminasi, mencegah mereka mencari bantuan kesehatan dengan segera, dan membuat mereka tidak menjalankan perilaku hidup yang sehat. Selain itu, perawat dan tenaga Kesehatan yang berjuang merawat pasien dengan adanya persepsi yang salah dan stigma yang buruk akan membuat tenaga Kesehatan tertekan, stress dan terisolasi sehingga menurunkan kinerja dan sistim imun yang mengakibatkan tenaga Kesehatan terpapar penyakit Covid-19 dan meninggal dunia, sejak maret- Nopember sebanyak 282 orang dokter dan perawat meninggal dunia akibat penyakit Covid-19 (Kompas.com, 2020).

Pemerintah, warga negara, media masa, influencer, dan komunitas memiliki peran penting dalam mencegah dan menghentikan persepsi dan stigma negatif di sekitar kita, khususnya yang diasosiasikan dengan tenaga Kesehatan, keluarga pasien dan pasien penyakit Covid-19. Studi pendahuluan terhadap 20 orang masyarakat di kecamatan Serang dengan wawancara, Sebagian besar masyarakat merasa takut cemas dan panik jika berdekatan dengan perawat, dokter dan tenaga 
Faletehan Health Journal, 8 (3) (2021) 203-209

www. journal.Ippm-stikesfa.ac.id/ojs/index.php/FHJ

ISSN 2088-673X | 2597-8667

Kesehatan lain yang bekerja di rumah sakit, apalagi jika harus bertemu dengan pasien covid. Trend dan issue yang beredar di masyarakat jika ada tetangga atau teman yang sakit covid maka anggota keluarga tidak diperbolehkan keluar rumah, berinteraksi dengan orang lain dan harus menjauh jika lewat depan rumah orang yang didiagnosa Covid-19. Menurut persepsi masyarakat, virus Covid-19 dapat terbang melalui udara dan akan terhirup masuk ke hidung orang yang sehat saat bernafas, dan sebagian masyarakat juga mengganggap penyakit Covid-19 merupakan penyakit yang menakutkan dan biasanya menyerang orang yang banyak dosanya. Melihat latar belakang diatas peneliti merasa tertarik untuk mengambil judul penelitian "Persepsi dan Stigma masyarakat tentang Covid-19 di Provinsi Banten. Tujuan peneliti mengambil judul diatas untuk mengetahui persepsi dan stigma masyarakat terhadap penyakit Covid-19, agar dapat menghapus persepsi dan stigma negatif masyarakat terhadap peugas Kesehatan, keluarga pasien dan pasien yang menderita penyakit Covid-19.

\section{Metodologi Penelitian}

Desain penelitian yang digunakan yaitu penelitian kuantitatif dengan menggunakan pendekatan studi potong lintang bersifat deskriptif analitik untuk melihat persepsi dan stigma masyarakat yang berhubungan dengan penyakit Covid-19 di Banten. Variabel Independen pada penelitian ini yaitu persepsi dan stigma masyarakat, dan variabel dependennya adalah penyakit Covid-19. Penyakit Covid-19 dalam penelitian ini dikategorikan menjadi dua yaitu pengaruh buruk dan pengaruh baik. Penelitian ini dilakukan pada bulan Juni - Nopember 2020 di Kecamatan Kota Serang dan Kecamatan Jiput Kabupaten Pandeglang dengan jumlah sampel 750 responden, yang berasal dari masyarakat. Pengambilan sampel dengan tehnik Purposive sampling, dengan kreteria inklusi: masyarakat Kota Serang dan Kabupaten Pandeglang, usia $>18$ tahun, memahami Bahasa Indonesia, Pendidikan minimal SMP, bersedia menjadi responden. Kriteria ekslusi: keluarga/tetangga dari responden yang menghalangi responden untuk memahami/atau mengisi kuisioner. Instrumen penelitian menggunakan kuisioner yang diberikan langsung pada responden untuk diisi dengan melalui proses wawancara. uji validitas kuisioner dilakukan terhadap 30 orang yang tidak termasuk dalam sampel. Hasil uji coba dengan menggunakan product moment didapatkan nilai $\mathrm{r}$ hitung 0,274 diatas $r$ tabel, maka item soal dinyatakan valid. Uji Reliabilitas menggunakan Chronbach's Alfa didapatkan nilai Alfa 0,764 berarti dapat diterima.

Data yang terkumpul dilakukan analisa Univariat dan Bivariat dengan pendekatan uji Chi Square. Sebelum melakukan penelitian, peneliti meminta ijin kepada Kepala Dinas Kesehatan Provinsi Banten dan pihak terkait untuk melakukan penelitian, Nomor: 440/3664/SDKP/2020, penelitian ini dilakukan uji etik oleh LPPM Untirta dengan Nomor: 258/UN43.20/PM.01.01/2020.

\section{Hasil dan Pembahasan}

Sebaran distribusi responden menurut jenis kelamin, dari tabel 1 menunjukan bahwa sebagian besar responden berjenis kelamin perempuan 502 $(66,9 \%)$. Responden menurut umur 18-30 tahun $396(52,8 \%)$, dan umur 31- 40 tahun 250 (33,3\%). persepsi negatif sebanyak $473(63,1 \%)$, sedangkan masyarakat yang persepsi positif sebanyak 277 $(36,9 \%)$. Masyarakat yang mempunyai stigma positif sebanyak $378(50,4 \%)$, sedangkan yang mempunyai sikap negatif $372(49,6 \%)$.

Tabel 1. Distribusi Responden Menurut Jenis Kelamin, Umur, Persepsi, dan Stigma Terhadap Penyakit Covid-19 $(n=750)$

\begin{tabular}{lcc}
\hline $\begin{array}{c}\text { Karakteristik } \\
\text { Responden }\end{array}$ & n & \% \\
\hline $\begin{array}{l}\text { Jenis Kelamin } \\
\text { Laki-laki }\end{array}$ & 248 & 33,1 \\
Perempuan & 502 & 66,9 \\
\hline Umur & 396 & 52,8 \\
18 - 30 Tahun & 250 & 33,3 \\
31-40 Tahun & 40 & 5,3 \\
41-50 Tahun & 64 & 8,5 \\
$\quad>50$ Tahun & & \\
\hline Persepsi Positif & 277 & 36,9 \\
Positif & 473 & 63,1 \\
$\quad$ Negatif & & \\
\hline Stigma Negatif & 378 & 50,4 \\
Positif & 371 & 49,6 \\
$\quad$ Negatif & & \\
\hline
\end{tabular}

Berdasarkan tabel 2. responden yang memiliki persepsi negatif tentang penyakit Covid-19 sebanyak $74,0 \%$, dan responden yang mempunyai persepsi positif terdapat $59.6 \%$. Secara statistik hasil penelitian didapatkan nilai PValue $=0.00$, berarti ada hubungan yang signifikan antara persepsi masyarakat yang negatif tentang penyakit 
Covid-19 dengan pengaruh buruk bagi Tenaga Kesehatan dan pasien Covid-19. Analisis diatas didapatkan nilai $\mathrm{OR}=4.1 \mathrm{kali}$, yang artinya persepsi negatif masyarakat tentang Covid akan berpengaruh buruk sebesar 4.1 kali terhadap tenaga Kesehatan yang merawat pasien Covid-19, dibanding persepsi positif masyarakat terhadap tenaga Kesehatan yang merawat pasien Covid dan pasien Covid, serta keluarganya.

Dari tabel 3. Responden terbanyak terdapat pada stigma masyarakat yang negatif yaitu 275 responden (73.9\%), sedangkan responden yang mempunyai stigma positif ada 191 responden (50.5\%). Uji statistik didapatkan Pvalue $=0.00$, hal ini menunjukkan ada hubungan yang signifikan antara Stigma masyarakat yang negatif tentang penyakit Covid-19 dengan pengaruh buruk bagi tenaga Kesehatan dan pasien Covid-19. Dari analisis di atas didapatkan nilai $\mathrm{OR}=2.8$, yang artinya stigma negative masyarakat tentang tenaga Kesehatan, pasien covid-19, dan keluarga pasien akan berpengaruh buruk 2.8 kali terhadap petugas Kesehatan dan pasien penyakit Covid-19 dibandingkan dengan stigma positif masyarakat terhadap petugas Kesehatan dan pasien penyakit Covid-19, dan keluarganya.

\section{Persepsi Masyarakat Terhadap Penyakit Covid-19}

Berdasarkan hasil penelitian diatas menunjukkan ada hubungan yang signifikan antara persepsi masyarakat yang negatif tentang covid-19 dengan dampak pengaruh buruk bagi Tenaga Kesehatan, pasien penyakit Covid-19, dan keluarganya lebih besar dibandingkan persepsi positif. Dari beberapa artikel (Compass Parallax 9, 2019), mengemukakan pendapat terkait persepsi baik persepsi yang positif maupun negatif. Setiap orang bisa saja mempunyai persepsi yang berbeda meskipun objeknya sama. Hal tersebut dimungkinkan karena adanya perbedaan dalam sistem nilai dan ciri kepribadian dari individu yang bersangkutan.

Akbar, (2015), menjelaskan bahwa persepsi merupakan suatu proses dimana individu mengorganisasikan dan menafsirkan kesan-kesan indera mereka untuk memberikan makna terhadap lingkungan. Soedarsa, (2014) berpendapat bahwa persepsi merupakan suatu proses dimana seseorang mengorganisasikan dan menginterpretasikan kesan-kesan sensorinya dalam usaha memberikan suatu makna tertentu dalam lingkungannya. Buyung, (2016) menjelaskan bahwa persepsi sebagai proses mengetahui atau mengenali objek dan kejadian objektif dengan bantuan indera. Proses perceptual ini dimulai dengan perhatian, yaitu merupakan proses pengamatan selektif. Didalamnya mencakup pemahaman dan mengenali atau mengetahui objek-objek serta kejadiankejadian, Penelitian ini berbeda dengan penelitian Mourine V. Lomboan, Adisti A. Rumayar, 2020), yang menyatakan Persepsi masyarakat sudah baik, masyarakat paham tentang bahaya Covid-19 dan masyarakat juga paham dengan protocol kesehatan dalam pencegahan covid-19 sehingga masyarakat terus berupaya menerapkan anjuran pemerintah terkait protocol kesehatan.

Tabel 2. Distribusi Hubungan Persepsi Responden Terhadap Penyakit Covid-19 ( $\mathrm{n}=750$ )

\begin{tabular}{|c|c|c|c|c|c|c|c|}
\hline \multirow{3}{*}{ Persepsi } & \multicolumn{4}{|c|}{ Dampak Covid-19 } & \multirow{3}{*}{ Total } & \multirow{3}{*}{ Nilai $\mathbf{P}$} & \multirow{3}{*}{ OR $(95 \%$ CI $)$} \\
\hline & \multicolumn{2}{|c|}{ Pengaruh Buruk } & \multicolumn{2}{|c|}{ Pengaruh Baik } & & & \\
\hline & $\mathbf{n}$ & $\%$ & n & $\%$ & & & \\
\hline Negatif & 350 & 74 & 123 & 26 & 473 & & \\
\hline Positif & 112 & 40,4 & 165 & 50,5 & 277 & 0,00 & $4.193(3.057-5.749)$ \\
\hline Total & 462 & & 288 & & 750 & & \\
\hline
\end{tabular}

Tabel 3. Distribusi Hubungan Stigma masyarakat Dengan Covid-19 $(n=750)$

\begin{tabular}{|c|c|c|c|c|c|c|c|}
\hline \multirow{3}{*}{ Stigma } & \multicolumn{4}{|c|}{ Dampak Covid-19 } & \multirow{3}{*}{ Total } & \multirow{3}{*}{ Nilai $\mathbf{P}$} & \multirow{3}{*}{ OR $(95 \% \mathrm{CI})$} \\
\hline & \multicolumn{2}{|c|}{ Pengaruh Buruk } & \multicolumn{2}{|c|}{ Pengaruh Baik } & & & \\
\hline & $\mathbf{n}$ & $\%$ & $\mathbf{n}$ & $\%$ & & & \\
\hline Negatif & 275 & 73,9 & 97 & 26,1 & 372 & & \\
\hline Positif & 187 & 49,5 & 191 & 50,5 & 378 & 0,00 & $2.896(2.130-3.936)$ \\
\hline Total & 462 & & 288 & & 750 & & \\
\hline
\end{tabular}


Faletehan Health Journal, 8 (3) (2021) 203-209

www. journal.Ippm-stikesfa.ac.id/ojs/index.php/FHJ

Penelitian Mourine., Lomboan., Adisti., dan. Rumayar, (2020), yang menyatakan Perseps meskipun berdasarkan hasil analisis pelaksanaan pencegahan Covid-19 di Kelurahan Talikuran utara Kecamatan Kawangkoan Utara persepsi masyarakat sangat takut, khawatir dengan adanya wabah Covid-19 untuk itu masyarakat mengikuti anjuran, pemerintah agar mengikuti protocol Kesehatan guna mencegah penularan covid-19 dengan baik.

Hasil survey yang dilakukan oleh Kiswantoro dan Damiasih, (2018), menyatakan persepsi merupakan pengalaman tentang objek maupun peristiwa yang dapat berhubung dengan menyimpulkan informasi dan menafsirkan peran.1 penelitian Pennycook et al., (2020) mengatakan "Masyarakat lebih cenderung membagikan persepsi dari berita utama yang sebenarnya dibandingkan dengan berita utama yang salah setelah mereka menilai keakuratan satu judul yang tidak terkait COVID;. Secara khusus, meskipun peserta dalam kondisi kontrol tidak secara signifikan.

Persepsi tentang penyakit Covid-19 pada masyarakat di Banten ini untuk tenaga Kesehatan, pasien penyakit Covid-19, dan keluarga pasien Penyakit Covid-19, rata rata negatif, dengan menganggap semua yang berhubungan dengan penyakit Covid-19, adalah berbahaya, menakutkan, harus dihindari, dan dikucilkan. Sigma penyakit Covid-19 akan menular, dan mengakibatkan kematian, oleh karenanya penderita harus di jauhi. Stigma tersebut berkembang disebabkan kurangnya pengetahuan dan pemahaman masyarakat tentang penyakit Covid-19, meskipun pemerintah dan tenaga Kesehatan telah memberikan penjelasan dan penyuluhan kepada masyarakat melalui media massa Televisi, Radio, Youtube, Koran dan lainnya.

\section{Hubungan Stigma Masyarakat Tentang Penyakit Covid-19}

Berdasarkan hasil penelitian ini menunjukkan ada hubungan yang signifikan antara Stigma masyarakat yang negatif tentang penyakit Covid19 dengan pengaruh buruk bagi tenaga kesehatan, pasien penyakit Covid-19, dan keluarganya dibandingkan stigma positif. Hasil penelitian Pennycook et al., (2020), menyatakan ada hubungan antara pernyataan/stigma yang baik dengan kondisi yang baik bagi pasien Covid-19 sehingga tingkat penyembuhan pasien covid-19 juga semakin baik. Hasil penelitian Kustanti et al., 2015; Mourine., Lomboan., Adisti., dan Rumayar, 2020; Popov, (2006), menyatakan ada hubungan yang signifikan antara stigma dengan kualitas hidup pasien HIV/AIDS dengan kekuatan sedang, dan arah korelasi negatif yang artinya semakin tinggi stigma negatif maka semakin rendah kualitas hidup pasien HIV/AIDS. Secara konsep stigma sangat berpengaruh terhadap kualitas hidup, karena salah satu dampak dari stigma adalah penyangkalan atau pembatasan pada layanan kesehatan, selain itu bayangan dan perasaan orang yang terstigma secara internal akan sangat mempengaruhi upaya pencegahan (Ismayadi, 2016).

Stigmatisasi merupakan sebuah proses hadir dan berkembangnya sebuah pandangan negatif tentang individu/kelompok diakibatkan sebuah gejala sosial (Dai, 2020). Menurut Ismayadi (2016), stigma merupakan gambaran dari keadaan ataupun kondisi yang berkaitan dengan sudut pandang atau sesuatu yang dianggap bernilai kurang baik atau negatif. Ismayadi (2016) juga mengatakan stigma juga dipahami sebagai konstruksi sosial dengan memberikan ciri yang membedakan aib sosial melekat pada orang lain sehingga dapat mengidentifikasi dan mengevaluasi termasuk mengingat orang lain lebih cepat.

Sementara belum ada studi pendahuluan yang memetakan karakteristik stigma secara praktis untuk dimanfaatkan bagi tindakan preventif dan penanggulangan informasi yang simpang siur. Stigma harus dilihat secara satu kesatuan yang utuh karena stigma bukan hanya sebuah sikap atau perilaku pada suatu suasana yang menjadi tidak baik tapi stigma juga akan menimbulkan marginilasiasi, dan memperburuk status kesehatan dan tingkat kesembuhan. Inilah yang perlu dipahami bahwa stigma berkontribusi terhadap tingginya angka kematian.

Stigma yang di berikan masyarakat di Banten terhadap tenaga kesehatan, pasien Covid-19, dan keluarga pasien Covid-19, yaitu dengan menjauh, mengucilkan, mengisolasi dan melarang untuk mendekat, karena masyarakat menganggap tenaga Kesehatan, pasien Covid-19 dan keluarganya merupakan sumber penularan Covid-19 oleh karena itu harus di jauhi, di isolasi dan didiskriminasi. 
Persepsi yang salah terhadap covid akan berdampak pada kinerja tenaga Kesehatan dalam melakukan pelayanan kepada masyarakat khususnya pada pasien Covid-19, demikian juga terhadap pasien covid-19 persepsi yang negative akan mengakibatkan pasien depresi sehingga menurunkan sistim imunitasnya sehingga akan memperparah penyakitnya yang berakibat kematian.

Setiap orang mempunyai persepsi sendiri mengenai apa yang dilihat, dipikirkan, dan dirasakan, hal tersebut sekaligus berarti bahwa persepsi menentukan apa yang akan diperbuat seseorang untuk memenuhi, berbagai kepentingan baik untuk diri sendiri, keluarga maupun lingkungan masyarakat tempat berinteraksi. Persepsi inilah yang membedakan seseorang dengan yang lain. Menurut (Asha \& Wanto, 2020) Persepsi dihasilkan dari konkritisasi pemikiran, kemudian melahirkan konsep atau ide yang berbeda beda dari masing-masing orang meskipun objek yang dilihat sama.

Hasil survey yang dilakukan Setiawan, (2020), menyatakan persepsi merupakan pengalaman tentang objek maupun peristiwa yang dapat berhubung dengan menyimpulkan informasi dan menafsirkan peran. Hasil penelitian (Pennycook et al., 2020) mengatakan "Masyarakat lebih cenderung membagikan persepsi dari berita utama yang sebenarnya dibandingkan dengan berita utama yang salah setelah mereka menilai keakuratan satu judul yang tidak terkait penyakit Covid-19". Secara khusus, meskipun peserta dalam kondisi kontrol tidak secara signifikan.

\section{Simpulan}

Berdasarkan hasil analisis dan pembahsan penelitian ini, maka dapat diambil kesimpulan bahwa terdapat hubungan yang signifikan antara persepsi masyarakat yang negatif tentang penyakit Covid-19 dengan pengaruh buruk bagi tenaga kesehatan, pasien covid-19 dan keluarga pasien. stigma masyarakat yang negatif tentang penyakit Covid-19 berhubungan dengan pengaruh buruk bagi tenaga Kesehatan, pasien covid-19 dan keluaraga. Persepsi merupakan variabel yang paling dominan terhadap penyakit Covid-19.

\section{Referensi}

Arifiati, N., Nurkhayati, E., Nurdiawati, E., Pamungkas, G., Adha, S., Purwanto, A., Julyanto, O., \& Azizi, E. (2020). University
Students Online Learning System During Covid-19 Pandemic: Advantages, Constraints and Solutions. Systematic Reviews in Pharmacy, 11(7), 570-576.

Asha, L., \& Wanto, D. (2020). Persepsi Masyarakat Sukaraja , Rejang Lebong Terhadap Edaran Menteri Agama Nomor : SE . 6. Tahun 2020 Mengenai Tata Cara beribadah Saat Pandemi. Jurnal Peneltian Dan Pengabdian Masyarakat (MANHAJ), 9(1), $\quad 1-17$. https://ejournal.iainbengkulu.ac.id/index.php/ manhaj/article/view/3268

Bafadhal, O. M. (2020). Memetakan Pesan Hoaxs Berita Covid-19 Di Indonesia. Lintas Kategori, Sumber, Dan Jenis Disinformasi. Jurnal Magister Ilmu Komunikasi 6 (02), 235 249

Buyung. (2016). Jurnal Ilmiah DIKDAYA PENGARUH PERSEPSI SISWA TENTANG MATEMATIKA TERHADAP HASIL BELAJAR MATEMATIKA DI SMP Buyung 1. Dikdaya, 1, 20-28.

Dai, N. F. (2020). Stigma Masyarakat Terhadap Pandemi Covid-19. Prodi Ilmu Keperawatan Universitas Indonesia Timur, 66-73.

Compass, $\quad$ Parallax 9 (2019). https://doi.org/10.4324/9781003060918-2

Indonesia, P. R. (2020). KEPPRES NO 12 TH $2 \mathrm{O} 2 \mathrm{O}$ Tentang Penetapan Bencana Nonalam Penyebaran Corona Virus Disease 2019 Sebagai Bencana Nasional. Fundamental of Nursing, $01,18=30$.

Ismayadi, I. (2016). Hubungan Stigma, Depresi Dan Kelelahan Dengan Kualitas Hidup Pasien Hiv/Aids Di Klinik Veteran Medan. Idea Nursing Journal, 7(1), 1-13.

Japardi, I. (2003). Jurnal Keperawatan Indonesia. Jurnal Keperawatan Indonesia, 7(1), 32-35. http://www.jki.ui.ac.id/index.php/jki/article/v iew/130/376

Kim, J., Zhang, J., Cha, Y., Kolitz, S., Funt, J., Chong, R. E., Barrett, S., Zeskind, B., Kusko, R., \& Kaufman, H. (2020). Coronavrus Disease - 2019 (COVID-19). ChemRxiv, 2019(February).

https://doi.org/10.26434/chemrxiv.12037416. v1

Kiswantoro, A., \& Damiasih, D. (2018). Persepsi Kualitas Layanan Museum Sebagai Sarana Edukasi Masyarakat (Studi Kasus: Museum Gunung Api Merapi Yogyakarta). 
Faletehan Health Journal, 8 (3) (2021) 203-209

www. journal.Ippm-stikesfa.ac.id/ojs/index.php/FHJ

ISSN 2088-673X | 2597-8667

Kepariwisataan: Jurnal Ilmiah. https://www.academia.edu/download/572398 15/Jurnal_Sabda_2.pdf

Kumar, D. (2020). Corona Virus: A Review of COVID-19. Eurasian Journal of Medicine and Oncology, 4(2), 8-25. https://doi.org/10.14744/ejmo.2020.51418

Kustanti, A., Wijayanti, Y., Rahmat, I., Keperawatan, M., Mada, U. G., Dalam, D. P., Kedokteran, F., Mada, U. G., Ners, P. S., Kedokteran, F., \& Gadjah, U. (2015). Cross Cultural Skala Stigma Terkait HIV / AIDS Pada Mahasiswa Keperawatan. Jppni, 01(2), 145-153.

Mona, N. (2020). Konsep Isolasi Dalam Jaringan Sosial Untuk Meminimalisasi Efek Contagious (Kasus Penyebaran Virus Corona Di Indonesia). Jurnal Sosial Humaniora Terapan, 2(2), 117-125. https://doi.org/10.7454/jsht.v2i2.86

Mourine V. Lomboan, Adisti A. Rumayar, C. K. F. M. (2020). Gambaran Persepsi Masyarakat Tentang Pencegahan Covid-19 Di Kelurahan Talikuran Utara Kecamatan Kawangkoan Utara. Kesmas, 9(4), 111-117. https://ejournal.unsrat.ac.id/index.php/kesma s/article/view/29680/28743

Nuril Endi Rahman, Anita Wijaya Tyas, A. N. (2020). Hubungan Pengetahuan Tentang Covid-19 Terhadap Sikap Stigma Masyarakat Pada Orang Yang Bersinggungan Dengan Covid-19, vol.10, 2.

Pennycook, G., McPhetres, J., Zhang, Y., Lu, J. G., \& Rand, D. G. (2020). Fighting COVID-19 Misinformation on Social Media: Experimental Evidence for a Scalable Accuracy-Nudge Intervention. Psychological Science, 31(7), 770-780. https://doi.org/10.1177/0956797620939054

Popov, V. (2006). Relativistic kinetics of phonon gas in superfluids. General Relativity and Gravitation, 38(5), 917-935. https://doi.org/10.1007/s10714-006-0272-7

Sari, A. K., \& Febrianti, T. (2020). Gambaran Epidemiologi Dan Stigma Sosial Terkait Pandemi Covid- 19 Di Kota Tangerang Selatan Tahun 2020. Collaborative Medical Journal (Cmj), 3(3), 104-109

Setiawan, K. (2020). Komparasi Impresi Pandemi Covid-19 Terhadap Kehidupan Sosial Pelaku Usaha Perkebunan Kelapa Sawit Raykat Dan Swasta. Jurnal Syntax Transformation, 1(6),
278-284.

http://jurnal.syntaxtransformation.co.id/index .php/jst/article/view/56

Wanodya, K. S., \& Usada, N. K. (2020). Literature Review : Stigma Masyarakat Terhadap Covid - 19. Preventia: Indonesian Journal of Public Health, 5(2), 107-111. 